\title{
Biochemical compounds' dynamics during larval development of the carpet-shell clam Ruditapes decussatus (Linnaeus, 1758): effects of mono-specific diets and starvation
}

\author{
Domitília Matias · Sandra Joaquim • \\ Margarete Ramos $\cdot$ Paula Sobral $\cdot$ Alexandra Leitão
}

Received: 26 November 2009/Revised: 10 September 2010/Accepted: 29 September 2010/Published online: 27 October 2010

(C) Springer-Verlag and AWI 2010

\begin{abstract}
Successful larval growth and development of bivalves depend on energy derived from internal (endotrophic phase) and external (exotrophic phase) sources. The present paper studies survival, growth and biochemical changes in the early developmental stages (from egg to pediveliger) of the clam Ruditapes decussatus in order to characterize the nutritional requirements and the transition from the endotrophic to the exotrophic phase. Three different feeding regimes were applied: starvation and two mono-specific microalgal diets (Isochrysis aff galbana and Chaetoceros calcitrans). A comparison between fed and unfed larvae highlighted the importance of egg lipid reserves, especially neutral lipids, during a brief endotrophic phase of embryonic development (first 2 days after fertilization). Egg reserves, however, may energetically contribute to the maintenance of larvae beyond the embryonic development. In fed larvae, the endotrophic phase is followed by a mixotrophic phase extending to days 5-8 after fertilization and a subsequent exotrophic phase. Metamorphosis starts around day 20. The intense embryonic activities are supported by energy derived from lipids, mainly from neutral lipids, and the metamorphic activities are supported by energy derived essentially from proteins accumulated during the planktonic phase and depend on the nutritional value of diets. The diet of I. aff galbana
\end{abstract}

Communicated by H.-D. Franke.

D. Matias $(\bowtie) \cdot$ S. Joaquim · M. Ramos · A. Leitão

Instituto Nacional de Recursos Biológicos, I.P./L-IPIMAR,

Av. 5 de Outubro, 8700-305 Olhão, Portugal

e-mail: dmatias@ipimar.pt

P. Sobral

IMAR, Faculdade de Ciências e Tecnologia,

Universidade Nova de Lisboa, 2829-516 Caparica, Portugal proves to be more adequate to $R$. decussatus larval rearing. The results provide useful information for the successful production of $R$. decussatus aquaculture.

Keywords Bivalve larvae - Ruditapes decussatus . Biochemical composition - Nutritional phases .

Starvation $\cdot$ Diet

\section{Introduction}

The clam Ruditapes decussatus is widely distributed along the coastal and estuarine areas of Europe and North Africa and has high commercial value. Nevertheless, information on its biology and especially its larval phase is very limited (Chícharo and Chícharo 2001; Beiras and Albentosa 2004).

The major morphological changes in bivalve development occur during embryogenesis and metamorphosis. Successful bivalve larval growth and development depend on the energy available during the endotrophic and the subsequent exotrophic developmental phases (Labarta et al. 1999b; Pernet et al. 2004). The endotrophic phase largely corresponds to the embryonic development and is mainly managed by endogenous reserves provided to the eggs during oogenesis (Bayne 1973). The subsequent exotrophic phase, which leads to larval metamorphosis, depends on the value of the diet provided to promote larval growth (Whyte et al. 1990). Both phases are characterized by intense morphogenetic activities, while there is only a small increase in size (Bayne et al. 1975). The transition from the endotrophic to the exotrophic phase seems to be gradual; larvae initiate feeding while still using their yolk reserves. There are only a few published studies on this transitional phase (Lucas et al. 1986; Delaunay 1992; RicoVilla et al. 2009). 
The roles of tissue proteins, lipids and carbohydrates differ among bivalve species. The viability of bivalve larvae is limited by the accumulation and/or utilization of either lipids (Millar and Scott 1967; Helm et al. 1973; Holland and Spencer 1973) or proteins (Bartlett 1979; Rodríguez et al. 1990), but not carbohydrates (Collyer 1957; Holland and Spencer 1973; Bartlett 1979; Gallager and Mann 1986; Gallager et al. 1986; Labarta et al. 1999a), although Haws et al. (1993) suggested that carbohydrates may play a part in the optimal utilization of other reserves.

The importance of lipids as an energy reserve in pelagic veliger larvae and the relationship between maximal viability and survival of cultured larvae and the initial lipids (especially neutral lipids) content have been reported (Helm et al. 1973; Holland 1978; Gallager et al. 1986; Ferreiro et al. 1990). There is also evidence that lipids accumulated during the pelagic larval phase are used as the principal energy substrates during metamorphosis in several bivalve species (Holland and Spencer 1973; Gabbott 1976). In contrast, Bartlett (1979) demonstrated that Crassostrea gigas accumulates more energy in the form of proteins than in the form neutral lipids, suggesting that in this species, proteins is the basic energy reserve during metamorphosis. Similar observations were made by Rodríguez et al. (1990) for Ostrea edulis.

In the present study, we compare fed and unfed $R$. decussatus larvae in order to evaluate the development and duration of the endotrophic/exotrophic transition period and to understand the selective use of the different biochemical substrates in both absolute and energetic terms during larval development. A better understanding of the species' energy metabolism and nutritional requirements would be relevant to the successful production of R. decussatus in aquaculture.

\section{Materials and methods}

Microalgae culture conditions

The microalgae Isochrysis aff galbana (T-iso) and Chaetoceros calcitrans (C.cal) were reared in 10-1 flasks with $\mathrm{f} / 2$ medium (Guillard 1975) in a temperature-controlled room at $20 \pm 2{ }^{\circ} \mathrm{C}$ under continuous illumination. Seawater (salinity $=36 \pm 1 \%$ ) was filtered $(0.45 \mu \mathrm{m})$ and UV-treated. A continuous aeration was provided to enhance growth and prevent the algae from settling. Algae were harvested when the culture had reached the stationary growth phase. Before being used as food, algal cells were counted with a Coulter Counter TA II, $100 \mu \mathrm{m}$, from aliquots of $0.5 \mathrm{ml}$ from each culture.
Broodstock conditioning

Adult $R$. decussatus ( $>35 \mathrm{~mm}$ shell length) were collected in March 2006 from Ria de Aveiro $\left(40^{\circ} 42^{\prime} \mathrm{N} ; 08^{\circ} 40^{\prime} \mathrm{W}\right)$ (western coast of Portugal). Broodstock clams were conditioned at $20 \pm 1{ }^{\circ} \mathrm{C}$ for 2 months to speed up their gonad development. Clams were continuously fed a mixture of T-iso and C.cal $\left(5 \times 10^{8}\right.$ cells ind $\left.{ }^{-1} \mathrm{~d}^{-1}\right)$ in a $1: 1$ ratio in terms of size, the dry weight of algae corresponding to $4 \%$ of the dry weight of the clams' soft tissue (Utting and Millican 1997). The water was enriched with this mixed diet and distributed to the tanks at a flow rate of $0.6-0.81 \mathrm{~min}^{-1}$. Clams were induced to spawn by a rapid increase in temperature from $20^{\circ} \mathrm{C}$ to $28 \pm 1^{\circ} \mathrm{C}$ over a 6-h interval.

\section{Experimental design}

Oocytes from all females spawned $(n=5)$ were pooled and mixed with sperm (about ten spermatozoids per oocyte) for fertilization. Fertilized eggs were collected on a sieve, washed with filtered seawater and redistributed in a known volume of filtered seawater, subsampled and counted. Three samples of about 50,000 eggs each were taken for biochemical analyses, and a sample of 50 eggs was also taken for diameter measurement. The fertilized eggs were incubated in triplicate 5-1 tanks, with filtered $\mathrm{UV}$-irradiated seawater, maintained at $22 \pm 1{ }^{\circ} \mathrm{C}$, at a density of 100 eggs per $\mathrm{ml}$ with slight aeration. After $48 \mathrm{~h}$, the D-larvae were collected on a $30-\mu \mathrm{m}$ mesh screen, and the total number of veligers was calculated based on two 1-ml aliquots. The early D-larvae collected were dispensed at an initial density of $10 \pm 2$ larvae $\mathrm{ml}^{-1}$ in 5-1 tanks with natural filtered seawater $(0.45 \mu \mathrm{m})$ and reared in triplicate under three nutritional regimes: unfed and fed with mono-specific algae (T-iso and C.cal, respectively). Food was added daily to each tank at a rate of 50 cells $\mu \mathrm{l}^{-1}$. Salinity was $36 \pm 1 \%$, and temperature was maintained at $22 \pm 1^{\circ} \mathrm{C}$. Water was renewed every 2-3 days. At each time, samples were taken from each tank in order to estimate survival and mean shell length and to detect the presence of foot and/or any morphological alterations in the velum. Samples of 5,000 larvae each were also taken for biochemical analyses on days 2, $5,8,14,19$ and 23. Remaining larvae were transferred to the tanks.

Percent larval survival was determined at each water renewal. Anteroposterior shell length was measured for 50 randomly sampled larvae from each replicate using an ocular micrometer. Linear regressions were fitted to length over larval growth trajectories to determine length growth rates from eggs to metamorphic larvae for each treatment. 
The presence of a foot was scored to determine larval development status. Larvae that showed a clearly visible foot bulging out of the shell (pediveligers) were considered metamorphosed.

\section{Biochemical composition of eggs and larvae}

Samples of eggs and larvae for biochemical analyses were rinsed with iso-osmotic ammonium formate $(3 \% \mathrm{w} / \mathrm{v})$ to remove salt, transferred to Eppendorf tubes, frozen and stored in liquid nitrogen and then freeze-dried. A microanalytical fractionated extraction scheme developed by Holland and Gabbott (1971) and Holland and Hannant (1973) was followed for the determination of the contents of biochemical components. Lyophilized samples were homogenized in $500 \mu \mathrm{l}$ distilled water using a sonicator. Samples were sonicated in an ice water bath for three intervals of $10 \mathrm{~s}$ at $20 \mathrm{~W}$ each to obtain a thoroughly homogenized sample. Separate samples $(200 \mu \mathrm{l})$ of the initial homogenate were taken for the analyses of total lipids, neutral lipids, proteins, total carbohydrates and free reducing sugars. Total lipid content was extracted by the method of Bligh and Dyer (1959) and taken up in $500 \mu \mathrm{l}$ chloroform.

Total lipids were determined by the methods of Marsh and Weinstein (1966) using tripalmitin as a standard, and the absorbance was determined at $375 \mathrm{~nm}$. Neutral lipids were determined in the same way as total lipids; $200-\mu 1$ samples of neutral lipids in chloroform were dried for $20 \mathrm{~min}$ at $100^{\circ} \mathrm{C}$ and used for determinations. Phospholipids were determined as the difference between total and neutral lipids.

Proteins were precipitated by cold 5\% trichloroacetic acid (TCA), and the precipitate was washed in warm $1.0 \mathrm{~N}$ $\mathrm{NaOH}$. Protein concentration was assayed by the method of Lowry et al. (1951), modified by Bensadoun and Weinstein (1976) and Hess et al. (1978), at $750 \mathrm{~nm}$ using serum albumin as a standard.

Hydrolyzed and unhydrolyzed samples of TCA supernatant were used for the determination of total carbohydrates and free reducing sugars by a modification of the method of Folin and Malmros (1929). The components were quantified with a ferricyanate reduction reaction at $420 \mathrm{~nm}$ using glucose as a standard.

The organic matter was the sum of proteins, total lipids and carbohydrates. Linear regressions were fitted to organic matter over larval growth trajectories to determine organic growth rates from eggs to metamorphic larvae for each nutritional condition.

Energy conversion factors used for lipid, carbohydrate and protein were $35.24,17.16$ and $18.00 \mathrm{~kJ} \mathrm{~g}^{-1}$, respectively (Beukema and De Bruin 1979).
Statistical analyses

Differences in survival, growth (shell length, shell length growth rate, organic matter and organic matter growth rate), biochemical composition and energy were tested by analyses of variance (ANOVA) or Kruskal-Wallis ANOVA on ranks whenever the assumptions of ANOVA failed among days of the same nutritional regime and between regimes. Percentage data were arcsine-transformed to normalize variance (Sokal and Rohlf 1981). Multiple pair comparisons among means were performed using the post hoc parametric Tukey test or the non-parametric Dunn's test.

\section{Results}

Survival and growth

Survivorship of starved larvae was high till day 5 after fertilization $(96.27 \pm 1.68 \%)$ but then showed a steep decline (Fig. 1). On day 23 (last record), $23.21 \pm 3.95 \%$ of the larvae (equivalent to $13,000 \pm 2,677$ larvae) were still active. In contrast, the survival of fed larvae showed a rather gradual decrease over the experimental period. This decrease was slightly more pronounced after day 14 , when metamorphosis began. Highest survival rates were observed in larvae fed with C.cal $(71.98 \pm 12.25 \%)$, although these values were not significantly different from those of larvae fed with T-iso $(67.00 \pm 13.70 \%)$. Significant differences in survival rates were, however, observed between unfed and fed larvae (K-W., $H=12.77, d f=2, P=0.002$ ).

The results for growth (length and organic matter) and the presence of foot in clam larvae under the three nutritional regimes are detailed in Table 1 . The diameter and organic matter of eggs (day 0 ) as well as the initial length and organic matter of the early D-veliger larvae (day 2) were the same for all three treatments. During the early developmental

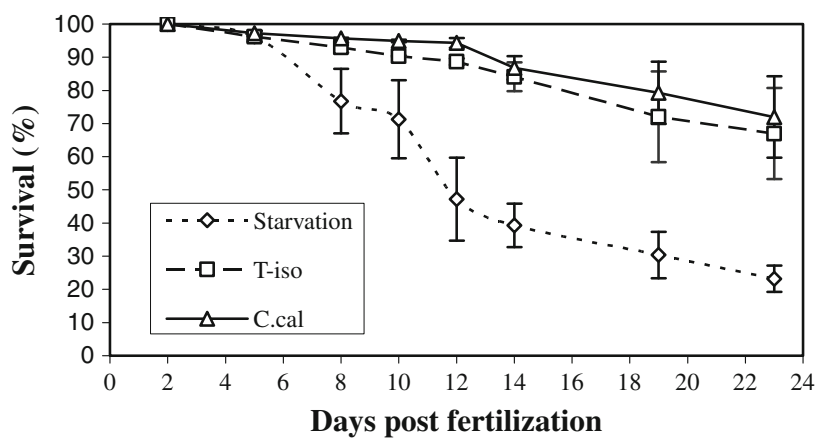

Fig. 1 Survival (mean $\pm \mathrm{SD}, n=6$ ) of Ruditapes decussatus larvae reared under three levels of nutrition: starvation and two monospecific diets (Isochrysis aff galbana $=\mathrm{T}$-iso and Chaetoceros calcitrans $=$ C.cal $)$ 
Table 1 Length (egg diameter and shell length, respectively; mean $\pm \mathrm{SD}, n=150$ ), larval length growth rate (mean $\pm \mathrm{SD}$, $n=3$ ), organic matter (mean $\pm \mathrm{SD}, n=3$ ), organic matter growth rate (mean $\pm \mathrm{SD}, n=3$ ) and presence of foot (\%) during the early

\begin{tabular}{|c|c|c|c|c|c|c|}
\hline Food regime & $\begin{array}{l}\text { Days after } \\
\text { fertilization }\end{array}$ & $\begin{array}{l}\text { Length } \\
\left(\mu \mathrm{m} \text { ind }^{-1}\right)\end{array}$ & $\begin{array}{l}\text { Larval length } \\
\text { growth rate } \\
\left(\mu \mathrm{m} \text { day }^{-1}\right)\end{array}$ & $\begin{array}{l}\text { Organic matter } \\
\left(\text { ng ind }^{-1}\right)\end{array}$ & $\begin{array}{l}\text { Organic matter } \\
\text { growth rate } \\
\left(\text { ng day }^{-1}\right)\end{array}$ & Foot $(\%)$ \\
\hline \multirow[t]{9}{*}{ Starvation } & 0 & $58.10 \pm 4.18$ & & $27.48 \pm 3.55$ & & \\
\hline & 2 & $96.71 \pm 5.98$ & & $29.59 \pm 1.65$ & & \\
\hline & 5 & $100.18 \pm 5.70$ & & $35.38 \pm 4.22$ & & \\
\hline & 8 & $99.18 \pm 4.30$ & & $26.59 \pm 5.35$ & & \\
\hline & 10 & $101.36 \pm 5.60$ & & - & & \\
\hline & 12 & $102.31 \pm 4.45$ & & - & & \\
\hline & 14 & $102.27 \pm 6.05$ & & $14.59 \pm 1.02$ & & \\
\hline & 19 & $104.53 \pm 6.64$ & & $10.38 \pm 1.71$ & & \\
\hline & 23 & $103.75 \pm 13.70$ & $0.33 \pm 0.09$ & $8.16 \pm 0.63$ & $-0.91 \pm 0.02$ & 0.00 \\
\hline \multirow[t]{9}{*}{ T-iso } & 0 & $58.10 \pm 4.18$ & & $27.48 \pm 3.55$ & & \\
\hline & 2 & $96.71 \pm 5.98$ & & $29.59 \pm 1.65$ & & \\
\hline & 5 & $103.53 \pm 5.02$ & & $113.19 \pm 12.95$ & & \\
\hline & 8 & $112.48 \pm 4.69$ & & $199.19 \pm 15.24$ & & \\
\hline & 10 & $119.21 \pm 7.02$ & & - & & \\
\hline & 12 & $129.81 \pm 8.66$ & & - & & \\
\hline & 14 & $150.14 \pm 10.10$ & & $232.78 \pm 26.24$ & & \\
\hline & 19 & $179.25 \pm 9.72$ & & $431.84 \pm 71.31$ & & \\
\hline & 23 & $184.03 \pm 9.32$ & $4.69 \pm 0.12$ & $322.17 \pm 7.56$ & $16.14 \pm 1.30$ & 75.66 \\
\hline \multirow[t]{9}{*}{ C.cal } & 0 & $58.10 \pm 4.18$ & & $27.48 \pm 3.55$ & & \\
\hline & 2 & $96.71 \pm 5.98$ & & $29.69 \pm 2.03$ & & \\
\hline & 5 & $104.27 \pm 6.50$ & & $80.65 \pm 6.11$ & & \\
\hline & 8 & $134.81 \pm 15.30$ & & $96.65 \pm 2.93$ & & \\
\hline & 10 & $153.88 \pm 6.46$ & & - & & \\
\hline & 12 & $161.53 \pm 9.99$ & & - & & \\
\hline & 14 & $168.48 \pm 11.64$ & & $149.98 \pm 11.83$ & & \\
\hline & 19 & $174.39 \pm 13.36$ & & $180.98 \pm 15.82$ & & \\
\hline & 23 & $199.67 \pm 12.19$ & $4.95 \pm 0.02$ & $143.20 \pm 7.78$ & $6.31 \pm 0.31$ & 42.81 \\
\hline
\end{tabular}

development of the clam Ruditapes decussatus under three levels of nutrition: starvation and two mono-specific diets (Isochrysis aff galbana $=\mathrm{T}$-iso and Chaetoceros calcitrans $=$ C.cal $)$ stages (from egg to early D-veliger larva), organic matter remained almost constant $\left(27.48 \pm 3.55 \mathrm{ng}\right.$ ind $^{-1}$ to $29.59 \pm$ $1.65 \mathrm{ng}$ ind $^{-1}$ ).

The growth rate of unfed larvae was only $0.33 \mu \mathrm{m} \mathrm{day}^{-1}$, but significant differences in larval growth were found among days after fertilization (K-W., $H=82.45, d f=7$, $P<0.001)$. In terms of organic matter, a sudden decrease was observed especially following day 5 after fertilization. When expressed as change in organic matter, negative values for growth rates were obtained $\left(-0.91 \pm 0.02 \mathrm{ng}\right.$ ind $\left.^{-1}\right)$, indicating a progressive decrease in the organic tissue of unfed larvae.

In contrast, larvae reared with the mono-specific diets showed an increase in length and also in organic matter. Larvae fed with C.cal had the highest length growth rate $\left(4.95 \pm 0.02 \mu \mathrm{m} \mathrm{day}^{-1}\right)$, while larvae fed with $\mathrm{T}$-iso showed the highest organic matter growth rate $(16.14 \pm$ $1.30 \mathrm{ng}$ day $\left.^{-1}\right)$. The percentage of foot presence at day 23 was higher in larvae fed with T-iso $(75.66 \%)$ than in those fed with C.cal $(42.81 \%)$. Significant differences among the three nutritional regimes were observed in length $(\mathrm{K}-\mathrm{W}$., $H=908.03, d f=2, \quad P \leq 0.001)$, length growth rate (ANOVA, $F=2,533.93, d f=2, P<0.001$ ) and organic matter growth rate (ANOVA, $F=365.81, \quad d f=2$, $P<0.001)$. With respect to organic matter, however, significant differences were found only between fed and unfed larvae (K-W., $H=34.36, d f=2, P \leq 0.001)$.

Biochemical composition and energy contents

Data on the biochemical composition (proteins, total lipids and carbohydrates) of eggs and larvae are presented in 
Table 2 Principal biochemical composition (mean $\pm \mathrm{SD}$, $n=9$ ) of early developmental stages of the clam Ruditapes decussatus under three levels of nutrition: starvation and two mono-specific diets (Isochrysis aff galbana $=\mathrm{T}$-iso and

Chaetoceros

calcitrans $=$ C.cal)

\begin{tabular}{|c|c|c|c|c|}
\hline \multirow[t]{2}{*}{ Food regime } & \multirow{2}{*}{$\begin{array}{l}\text { Days after } \\
\text { fertilization }\end{array}$} & \multicolumn{3}{|c|}{ Gross biochemical composition (ng ind ${ }^{-1}$ ) } \\
\hline & & Protein & Total lipids & Carbohydrates \\
\hline \multirow[t]{7}{*}{ Starvation } & 0 & $13.98 \pm 3.39$ & $8.10 \pm 2.40$ & $2.31 \pm 0.92$ \\
\hline & 2 & $14.77 \pm 0.57$ & $7.34 \pm 0.00$ & $4.14 \pm 0.14$ \\
\hline & 5 & $20.22 \pm 3.92$ & $7.24 \pm 0.83$ & $4.36 \pm 0.41$ \\
\hline & 8 & $13.49 \pm 6.84$ & $5.58 \pm 0.83$ & $4.29 \pm .47$ \\
\hline & 14 & $4.75 \pm 1.28$ & $2.82 \pm 1.26$ & $4.03 \pm 0.40$ \\
\hline & 19 & $2.39 \pm 1.26$ & $1.72 \pm 0.48$ & $3.51 \pm 0.20$ \\
\hline & 23 & $0.37 \pm 0.00$ & $1.72 \pm 0.48$ & $3.31 \pm 0.29$ \\
\hline \multirow[t]{7}{*}{ T-iso } & 0 & $13.98 \pm 3.39$ & $8.10 \pm 2.40$ & $2.31 \pm 0.92$ \\
\hline & 2 & $14.37 \pm 0.00$ & $7.34 \pm 0.00$ & $4.14 \pm 0.14$ \\
\hline & 5 & $54.86 \pm 14.13$ & $25.16 \pm 1.91$ & $16.56 \pm 0.92$ \\
\hline & 8 & $84.46 \pm 11.48$ & $61.28 \pm 2.66$ & $34.64 \pm 1.03$ \\
\hline & 14 & $101.28 \pm 26.23$ & $72.59 \pm 4.14$ & $39.01 \pm 1.73$ \\
\hline & 19 & $212.94 \pm 55.97$ & $151.18 \pm 30.41$ & $46.26 \pm 9.47$ \\
\hline & 23 & $144.33 \pm 11.65$ & $118.09 \pm 8.27$ & $38.29 \pm 4.56$ \\
\hline \multirow[t]{7}{*}{ C.cal } & 0 & $13.98 \pm 3.39$ & $8.10 \pm 2.40$ & $2.31 \pm 0.92$ \\
\hline & 2 & $14.37 \pm 0.00$ & $7.34 \pm 0.00$ & $4.14 \pm 0.14$ \\
\hline & 5 & $36.70 \pm 2.02$ & $21.58 \pm 4.08$ & $19.56 \pm 0.85$ \\
\hline & 8 & $27.96 \pm 3.08$ & $46.39 \pm 1.72$ & $20.41 \pm 1.13$ \\
\hline & 14 & $68.99 \pm 5.34$ & $53.01 \pm 9.11$ & $18.59 \pm 1.03$ \\
\hline & 19 & $85.81 \pm 13.44$ & $56.04 \pm 2.48$ & $32.55 \pm 1.16$ \\
\hline & 23 & $72.35 \pm 5.08$ & $47.22 \pm 4.99$ & $23.78 \pm 6.21$ \\
\hline
\end{tabular}

Table 2. Proteins and total lipids were the major biochemical components of early stages of $R$. decussatus. Proteins and total lipids remained almost constant until the early D-veliger stage $\left(13.98 \pm 3.39\right.$ to $14.77 \pm 0.57 \mathrm{ng}^{-1}$

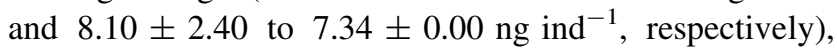
while carbohydrates nearly duplicated $(2.31 \pm 0.92$ to $4.14 \pm 0.14 \mathrm{ng}^{-1} \mathrm{ind}^{-1}$ ) during this period. Generally, after embryogenesis and trochophore development (day 2 after fertilization), the above biochemical components tended to increase in fed veligers till day 19 but decreased between days 19 and 23. Larvae fed with T-iso presented the highest increase in all three biochemical components. Protein contents increased from $14.77 \pm 0.57$ to $144.33 \pm$ $11.65 \mathrm{ng} \mathrm{ind}^{-1}$ (T-iso) and $72.35 \pm 5.08 \mathrm{ng} \mathrm{ind}^{-1}$ (C.cal), and total lipids from $7.34 \pm 0.00$ to $118.09 \pm 8.27 \mathrm{ng}^{-1}$ (T-iso) and $47.22 \pm 4.99 \mathrm{ng}^{-1} \mathrm{ind}^{-1}$ (C.cal). Carbohydrates showed the same tendency: in larvae fed with T-iso, their contents increased from $4.14 \pm 0.14$ to $38.29 \pm$

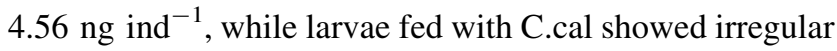
variations in carbohydrate contents after day 8 .

In the unfed culture (see also Fig. 2), the protein contents showed a slight initial increase between days 2 and 5, followed by an abrupt decrease to a minimum value of $0.37 \pm 0.00 \mathrm{ng} \mathrm{ind}^{-1}$ on day 23 , which represents a decrease of $27.81 \%$ in terms of total organic matter. A similar situation was observed for total lipids; the level remained

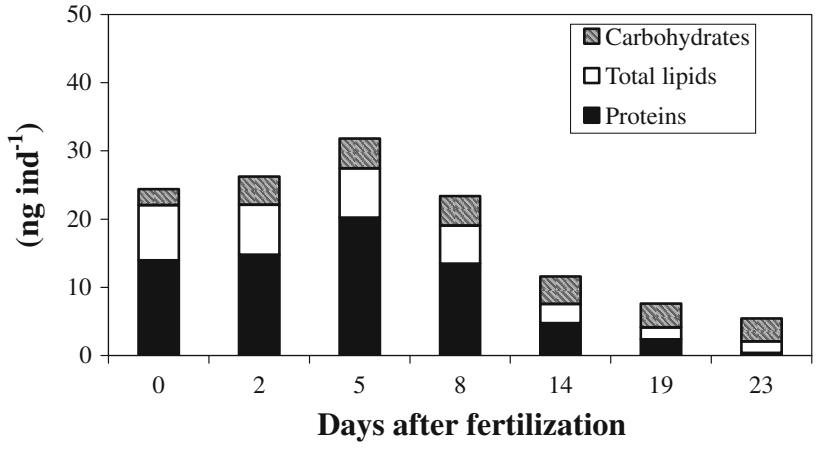

Fig. 2 Biochemical composition (mean $\pm \mathrm{SD}, n=9$ ) of early developmental stages of the clam Ruditapes decussatus reared without food

constant till day 5 followed by a gradual decline till the end of the experiment (day 2: $7.34 \pm 0.00 \mathrm{ng}^{-1} \mathrm{ind}^{-1}$; day 23: $1.72 \pm 0.48 \mathrm{ng}$ ind $^{-1}$ ), which represents a decrease of $12.94 \%$ in total organic matter. No significant changes were observed in proteins (K-W., $H=13.12, d f=4, P=0.011$, Dunn's Method-P>0.05) and total lipids (ANOVA, $F=26.93, d f=4, \quad P<0.001$, Tukey Test $-P>0.05)$ during the first 8 days after fertilization. Both components presented minimum values at the end of the experimental period (day 23). In contrast, the carbohydrate contents remained nearly constant throughout the experimental 
period. Significant differences were observed in biochemical composition (proteins-K-W., $H=32.99, d f=2, P \leq$ 0.001 ; total lipids-K-W., $H=34.03, d f=2, P \leq 0.00 ; 1$ and carbohydrates-K-W., $H=30.63, d f=2, P \leq 0.001$ ) between unfed and fed larvae.

The results for neutral lipids, phospholipids, free reducing sugars and polysaccharides in eggs and larvae under the three feeding regimes are shown in Table 3. The main contribution to total lipids came from neutral lipids. During the development from eggs to early D-veliger larvae, a slight reduction in energetic lipids (neutral lipids) was observed (from $7.30 \pm 2.43$ to $5.89 \pm 0.00 \mathrm{ng}^{\text {ind }}{ }^{-1}$ ), while structural lipids (phospholipids) increased (from $0.08 \pm 0.04$ to $1.45 \pm 0.00 \mathrm{ng}$ ind $^{-1}$ ) for all three treatments. The veliger larvae fed with $\mathrm{T}$-iso showed the greatest increase in both neutral lipids and phospholipids. Neutral lipids progressively increased till day 19 $\left(106.77 \pm 9.21 \mathrm{ng}\right.$ ind $\left.^{-1}\right)$ with a subsequent decrease till day $23\left(60.04 \pm 29.46 \mathrm{ng}\right.$ ind $\left.^{-1}\right)$. Phospholipid contents increased till day 23 when $58.04 \pm 27.34 \mathrm{ng}$ ind $^{-1}$ was attained. In larvae fed with C.cal, neutral lipids showed lower values (day 23:23.78 $\pm 6.21 \mathrm{ng}^{-1}$ ) but the same tendency as in larvae fed $\mathrm{T}$-iso. A rapid increase in phospholipid contents from day 5 to day 8 was followed by

Table 3 Neutral lipids, phospholipids, free reducing sugars and polysaccharides (mean $\pm \mathrm{SD}, n=9$ ) in the early developmental stages of the clam Ruditapes decussatus under three levels of a decrease between days 8 and 14, while the contents remained constant between days 14 and 23. In unfed larvae, the neutral lipid contents showed a significant decrease from day 5 to day 14 (ANOVA, $F=33.16, d f=4$, $P<0.001)$, i.e., there was a rapid utilization of energetic lipid reserves, while the phospholipid contents did not vary significantly throughout the experiment (ANOVA, $F=0.58, d f=4, P=0.683$ ) (Table 3; Fig. 3). These findings give a clear idea of the pattern of neutral lipid

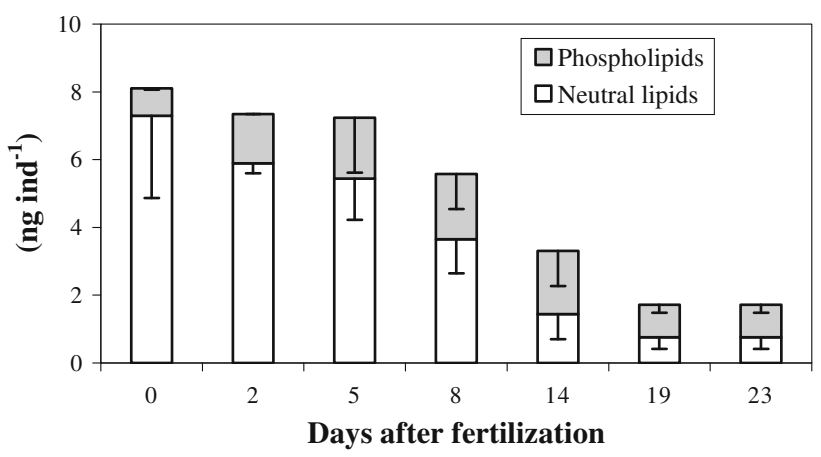

Fig. 3 Neutral lipids and phospholipids (mean $\pm \mathrm{SD}, n=9$ ) in early developmental stages of the calm Ruditapes decussatus reared without food

nutrition: starvation and two mono-specific diets (Isochrysis aff galbana $=\mathrm{T}$-iso and Chaetoceros calcitrans $=$ C.cal $)$

\begin{tabular}{|c|c|c|c|c|c|}
\hline \multirow[t]{2}{*}{ Food regime } & \multirow{2}{*}{$\begin{array}{l}\text { Days after } \\
\text { fertilization }\end{array}$} & \multicolumn{4}{|c|}{ Biochemical composition (ng ind ${ }^{-1}$ ) } \\
\hline & & Neutral lipids & Phospholipids & Free reducing sugars & Polysaccharides \\
\hline \multirow[t]{7}{*}{ Starvation } & 0 & $7.30 \pm 2.43$ & $0.08 \pm 0.04$ & $1.76 \pm 0.98$ & $0.56 \pm 0.15$ \\
\hline & 2 & $5.89 \pm 0.00$ & $1.45 \pm 0.00$ & $3.35 \pm 0.14$ & $0.78 \pm 0.00$ \\
\hline & 5 & $5.44 \pm 1.22$ & $1.79 \pm 1.72$ & $3.71 \pm 0.16$ & $0.65 \pm 0.32$ \\
\hline & 8 & $3.65 \pm 1.00$ & $1.93 \pm 1.04$ & $3.64 \pm 0.32$ & $0.65 \pm 0.20$ \\
\hline & 14 & $1.45 \pm 0.74$ & $1.86 \pm 1.04$ & $3.31 \pm 0.16$ & $0.72 \pm 0.29$ \\
\hline & 19 & $0.76 \pm 0.34$ & $0.97 \pm 0.24$ & $3.05 \pm 0.16$ & $0.46 \pm 0.16$ \\
\hline & 23 & $0.76 \pm 0.34$ & $0.97 \pm 0.24$ & $2.99 \pm 0.20$ & $0.32 \pm 0.17$ \\
\hline \multirow[t]{7}{*}{ T-iso } & 0 & $7.30 \pm 2.43$ & $0.08 \pm 0.04$ & $1.76 \pm 0.98$ & $0.56 \pm 0.15$ \\
\hline & 2 & $5.89 \pm 0.29$ & $1.45 \pm 0.00$ & $3.35 \pm 0.14$ & $0.78 \pm 0.00$ \\
\hline & 5 & $16.20 \pm 1.84$ & $8.96 \pm 1.57$ & $11.60 \pm 0.78$ & $4.96 \pm 0.92$ \\
\hline & 8 & $44.60 \pm 1.77$ & $16.68 \pm 3.34$ & $24.26 \pm 0.85$ & $10.38 \pm 0.54$ \\
\hline & 14 & $44.98 \pm 13.30$ & $26.61 \pm 18.19$ & $33.01 \pm 0.88$ & $6.00 \pm 1.86$ \\
\hline & 19 & $106.09 \pm 9.21$ & $45.09 \pm 23.55$ & $40.58 \pm 9.90$ & $5.68 \pm 2.49$ \\
\hline & 23 & $60.04 \pm 29.46$ & $58.04 \pm 27.34$ & $26.74 \pm 3.65$ & $11.32 \pm 4.58$ \\
\hline \multirow[t]{7}{*}{ C.cal } & 0 & $7.30 \pm 2.43$ & $0.08 \pm 0.04$ & $1.76 \pm 0.98$ & $0.56 \pm 0.15$ \\
\hline & 2 & $5.89 \pm 0.00$ & $1.45 \pm 0.00$ & $3.35 \pm 0.14$ & $0.78 \pm 0.00$ \\
\hline & 5 & $16.06 \pm 1.63$ & $5.52 \pm 4.82$ & $8.08 \pm 0.82$ & $11.49 \pm 1.39$ \\
\hline & 8 & $18.26 \pm 8.12$ & $31.50 \pm 13.41$ & $9.84 \pm 0.69$ & $10.57 \pm 1.53$ \\
\hline & 14 & $29.57 \pm 5.13$ & $23.44 \pm 9.31$ & $13.36 \pm 1.04$ & $5.22 \pm 1.48$ \\
\hline & 19 & $30.81 \pm 4.56$ & $23.99 \pm 3.51$ & $27.17 \pm 11.02$ & $5.38 \pm 1.51$ \\
\hline & 23 & $23.78 \pm 6.21$ & $23.44 \pm 8.91$ & $10.49 \pm 1.15$ & $4.05 \pm 0.99$ \\
\hline
\end{tabular}


utilization (13.18\% of organic matter) during the early development of $R$. decussatus. Significant differences were observed in neutral lipids (K-W., $H=29.90, d f=2$, $P \leq 0.001)$ and phospholipids (K-W., $H=27.58, d f=2$, $P \leq 0.001$ ) between unfed and fed larvae. Free reducing sugars and polysaccharides increased in all treatments during development from eggs to early D-veliger larvae. From the earliest shell stage to the pediveliger stage, the free reducing sugar levels in fed larvae increased from $3.35 \pm 0.14$ to $40.58 \pm 9.90 \mathrm{ng} \mathrm{ind}^{-1}$ (day 19) with a subsequent decrease till day $23\left(26.74 \pm 3.65 \mathrm{ng}\right.$ ind $\left.^{-1}\right)$ in larvae fed with $\mathrm{T}$-iso. Larvae fed with C.cal presented the same trend, with the highest value recorded on day 19 $\left(27.17 \pm 11.02 \mathrm{ng}\right.$ ind $\left.^{-1}\right)$. The polysaccharide contents of fed larvae increased until day 8 and then decreased till the end of experiment, except for the final measurement (day 23 ) in T-iso fed larvae. In the unfed culture, free reducing sugars remained almost constant over the experimental period and the same tendency was observed for the polysaccharide contents, although a slight decrease was detected following day 14. Significant differences were observed in free reducing sugars $(\mathrm{K}-\mathrm{W} ., \quad H=31.31, d f=2$, $P \leq 0.001)$ and polysaccharides $(\mathrm{K}-\mathrm{W} ., \quad H=29.42$, $d f=2, P<0.001)$ between unfed and fed larvae.

Table 4 Energy equivalents of the principal biochemical component (mean $\pm \mathrm{SD}, n=9$ ) of the early developmental stages of the clam Ruditapes decussatus reared under three levels of nutrition: starvation
Table 4 shows the energy content generated by each biochemical component analyzed and the total energy $\left(\mathrm{KJ}\right.$ ind $\left.^{-1}\right)$. The main contributions to the total energy came from proteins and total lipids. The energy generated by proteins and total lipids was approximately 40 and $50 \%$ of total energy, respectively, whereas carbohydrates contributed only with about $10 \%$. During larval development, significant differences were observed between unfed and fed larvae in terms of total energy (K-W., $H=28.95$, $d f=2, \quad P \leq 0.001)$ and energy generated by proteins (K-W., $H=28.25, d f=2, P \leq 0.001$ ), total lipids (K-W., $H=33.28, d f=2, P \leq 0.001)$ and carbohydrates $(\mathrm{K}-\mathrm{W}$., $H=23.67, d f=2, P \leq 0.001)$. In starved larvae, a gradual decrease in total energy and energy generated by proteins, lipids and carbohydrates was observed, representing a total of $0.51 \mathrm{~kJ}^{-1} \mathrm{ind}^{-1}$ consumed, from which more than $48 \%\left(0.24 \mathrm{~kJ}\right.$ ind $\left.^{-1}\right)$ corresponded to proteins, $46 \%\left(0.23 \mathrm{~kJ}\right.$ ind $\left.^{-1}\right)$ corresponded to total lipids and about $6 \%\left(0.03 \mathrm{~kJ}\right.$ ind $\left.^{-1}\right)$ being provided by carbohydrates. In the fed larvae, from the beginning of the larval period until the onset of the metamorphosis (day 19), there was a gradual increase in energy generated from proteins, total lipids and carbohydrates. It should be noted that from the onset of metamorphosis, there was a 25 and $20 \%$ loss of

and two mono-specific diets (Isochrysis aff galbana $=\mathrm{T}$-iso and Chaetoceros calcitrans $=$ C.cal)

\begin{tabular}{|c|c|c|c|c|c|}
\hline \multirow[t]{2}{*}{ Food regime } & \multirow[t]{2}{*}{ Days after fertilization } & \multicolumn{4}{|c|}{ Energy content $\left(\mathrm{KJ}\right.$ ind $\left.^{-1}\right)$} \\
\hline & & Proteins & Total lipids & Carbohydrates & Total energy \\
\hline \multirow[t]{7}{*}{ Starvation } & 0 & $0.25 \pm 0.06$ & $0.29 \pm 0.08$ & $0.04 \pm 0.02$ & $0.58 \pm 0.07$ \\
\hline & 2 & $0.26 \pm 0.00$ & $0.26 \pm 0.00$ & $0.10 \pm 0.00$ & $0.62 \pm 0.00$ \\
\hline & 5 & $0.36 \pm 0.06$ & $0.26 \pm 0.03$ & $0.09 \pm 0.02$ & $0.71 \pm 0.07$ \\
\hline & 8 & $0.24 \pm 0.10$ & $0.19 \pm 0.03$ & $0.06 \pm 0.01$ & $0.50 \pm 0.07$ \\
\hline & 14 & $0.09 \pm 0.03$ & $0.10 \pm 0.04$ & $0.03 \pm 0.01$ & $0.21 \pm 0.07$ \\
\hline & 19 & $0.04 \pm 0.02$ & $0.06 \pm 0.02$ & $0.01 \pm 0.00$ & $0.12 \pm 0.03$ \\
\hline & 23 & $0.01 \pm 0.00$ & $0.06 \pm 0.02$ & $0.01 \pm 0.00$ & $0.08 \pm 0.02$ \\
\hline \multirow[t]{7}{*}{ T-iso } & 0 & $0.25 \pm 0.06$ & $0.29 \pm 0.08$ & $0.04 \pm 0.02$ & $0.58 \pm 0.07$ \\
\hline & 2 & $0.26 \pm 0.00$ & $0.26 \pm 0.00$ & $0.10 \pm 0.00$ & $0.62 \pm 0.00$ \\
\hline & 5 & $0.99 \pm 0.25$ & $0.88 \pm 0.07$ & $0.28 \pm 0.01$ & $2.16 \pm 0.20$ \\
\hline & 8 & $1.52 \pm 0.21$ & $2.16 \pm 0.09$ & $0.59 \pm 0.01$ & $4.27 \pm 0.30$ \\
\hline & 14 & $1.82 \pm 0.47$ & $2.56 \pm 0.15$ & $0.67 \pm 0.01$ & $5.05 \pm 0.42$ \\
\hline & 19 & $3.83 \pm 1.01$ & $5.32 \pm 1.07$ & $0.79 \pm 0.16$ & $9.95 \pm 1.88$ \\
\hline & 23 & $2.60 \pm 0.21$ & $4.16 \pm 0.29$ & $0.66 \pm 0.08$ & $7.42 \pm 0.23$ \\
\hline \multirow[t]{7}{*}{ C.cal } & 0 & $0.25 \pm 0.06$ & $0.29 \pm 0.08$ & $0.04 \pm 0.02$ & $0.58 \pm 0.07$ \\
\hline & 2 & $0.26 \pm 0.00$ & $0.26 \pm 0.00$ & $0.10 \pm 0.00$ & $0.62 \pm 0.00$ \\
\hline & 5 & $0.66 \pm 0.04$ & $0.76 \pm 0.14$ & $0.34 \pm 0.01$ & $1.76 \pm 0.16$ \\
\hline & 8 & $0.50 \pm 0.06$ & $1.63 \pm 0.06$ & $0.35 \pm 0.01$ & $2.49 \pm 0.03$ \\
\hline & 14 & $1.24 \pm 0.10$ & $1.87 \pm 0.32$ & $0.32 \pm 0.02$ & $3.43 \pm 0.36$ \\
\hline & 19 & $1.41 \pm 0.03$ & $2.02 \pm 0.06$ & $0.56 \pm 0.20$ & $3.98 \pm 0.29$ \\
\hline & 23 & $1.30 \pm 0.09$ & $1.66 \pm 0.18$ & $0.25 \pm 0.02$ & $3.21 \pm 0.22$ \\
\hline
\end{tabular}


Table 5 Energy differentials during larval development of the clam Ruditapes decussatus reared under three levels of nutrition: starvation and two mono-specific diets (Isochrysis aff galbana $=$ T-iso and Chaetoceros calcitrans $=$ C.cal)

\begin{tabular}{|c|c|c|c|c|c|}
\hline \multirow[t]{2}{*}{ Food regime } & \multirow[t]{2}{*}{ Days after fertilization } & \multicolumn{4}{|c|}{ Energy differentials $\left(\mathrm{KJ}\right.$ ind $\left.^{-1}\right)$} \\
\hline & & Proteins & Total lipids & Carbohydrates & Total energetic \\
\hline \multirow[t]{6}{*}{ Starvation } & $0-2$ & $0.01 \pm 0.00$ & $0.03 \pm 0.00$ & $0.06 \pm 0.00$ & $0.04 \pm 0.00$ \\
\hline & $2-5$ & $0.11 \pm 0.03$ & $0.00 \pm 0.03$ & $0.01 \pm 0.02$ & $0.09 \pm 0.07$ \\
\hline & $5-8$ & $0.12 \pm 0.11$ & $0.06 \pm 0.05$ & $0.03 \pm 0.00$ & $0.21 \pm 0.10$ \\
\hline & $8-14$ & $0.16 \pm 0.13$ & $0.10 \pm 0.06$ & $0.04 \pm 0.01$ & $0.29 \pm 0.09$ \\
\hline & $14-19$ & $0.04 \pm 0.03$ & $0.04 \pm 0.04$ & $0.01 \pm 0.00$ & $0.09 \pm 0.06$ \\
\hline & $19-23$ & $0.04 \pm 0.02$ & $0.00 \pm 0.03$ & $0.00 \pm 0.01$ & $0.04 \pm 0.05$ \\
\hline \multirow[t]{6}{*}{ T-iso } & $0-2$ & $0.01 \pm 0.00$ & $\mathbf{0 . 0 3} \pm 0.00$ & $0.06 \pm 0.00$ & $0.04 \pm 0.00$ \\
\hline & $2-5$ & $0.73 \pm 0.25$ & $0.63 \pm 0.07$ & $0.21 \pm 0.01$ & $1.57 \pm 0.20$ \\
\hline & $5-8$ & $0.53 \pm 0.46$ & $1.27 \pm 0.09$ & $0.31 \pm 0.01$ & $2.12 \pm 0.50$ \\
\hline & $8-14$ & $0.30 \pm 0.46$ & $0.40 \pm 0.07$ & $0.08 \pm 0.01$ & $0.78 \pm 0.41$ \\
\hline & $14-19$ & $2.01 \pm 1.23$ & $2.77 \pm 0.97$ & $0.12 \pm 0.16$ & $4.90 \pm 1.82$ \\
\hline & $19-23$ & $1.24 \pm 1.08$ & $1.17 \pm 0.79$ & $0.14 \pm 0.24$ & $2.54 \pm 1.65$ \\
\hline \multirow[t]{6}{*}{ C.cal } & $0-2$ & $0.01 \pm 0.00$ & $0.03 \pm 0.00$ & $0.06 \pm 0.00$ & $0.04 \pm 0.00$ \\
\hline & $2-5$ & $0.40 \pm 0.04$ & $0.50 \pm 0.14$ & $0.26 \pm 0.01$ & $1.17 \pm 0.16$ \\
\hline & $5-8$ & $0.16 \pm 0.08$ & $0.87 \pm 0.11$ & $0.01 \pm 0.01$ & $0.73 \pm 0.18$ \\
\hline & $8-14$ & $0.74 \pm 0.15$ & $0.23 \pm 0.30$ & $0.03 \pm 0.02$ & $0.94 \pm 0.33$ \\
\hline & $14-19$ & $0.20 \pm 0.13$ & $0.07 \pm 0.47$ & $0.24 \pm 0.19$ & $0.50 \pm 0.79$ \\
\hline & $19-23$ & $0.11 \pm 0.10$ & $0.44 \pm 0.08$ & $0.31 \pm 0.23$ & $0.85 \pm 0.04$ \\
\hline
\end{tabular}

The increments represent the difference with the preceding stage

The values in bold type are negative

total energy per individual in larvae fed T-iso and C.cal, respectively.

The energy differentials for each component $\left(\mathrm{KJ}_{\mathrm{ind}}{ }^{-1}\right)$ at each different period of larval development are present in Table 5. During the development from eggs to early D-veliger larval stage (day 0-2), a negative differential was observed for the energy provided by total lipids, indicating that this component was consumed during this process, while during metamorphosis (day 19-23), negative differentials were observed for all components. In the larvae fed with $\mathrm{T}$-iso, the most important energy contribution to metamorphosis came from both proteins and total lipids. Carbohydrates also contributed, but to a lesser extent. However, in the larvae fed with C.cal, the most important energy contribution to metamorphosis came from total lipids.

\section{Discussion}

Larval forms often develop from small eggs with low energy content and are thus presumed to become dependent on exogenous food sources at an early stage of development. Endogenous egg reserves are known to be important for survival and growth throughout embryogenesis until exogenous food sources become available (Ojea et al.
2008). In the present study, larvae of $R$. decussatus survived for an extended period of time without access to algal food. The high survival rate of unfed larvae until day 5 after fertilization (76.78\%) suggests that egg reserves can contribute to the maintenance of larvae beyond the period of embryonic development. Even after 23 days of starvation (end of record), about $23 \%$ of the larvae were still swimming and did not show any signs of exhaustion. Apparently, larvae of $R$. decussatus, similar to those of C. gigas (Moran and Manahan 2004), have the capacity to survive without phytoplankton for long periods of time. During periods of low phytoplankton availability, larvae may rely on other external sources of energy for the maintenance of their metabolism until phytoplankton food becomes available and growth can occur. According to Moran and Manahan (2004) and Tang et al. (2005), unfed larvae of $C$. gigas and Meretrix meretrix, respectively, are not fully dependent upon their endogenous reserves to support maintenance metabolism. In our experiment, larvae were maintained in $0.45-\mu \mathrm{m}$ filtered seawater and could not have met their energy needs by phytoplankton or any large detrital material. Our results support the idea that $R$. decussatus larvae have complemented their nutritional requirements by alternative sources of energy such as dissolved organic material (DOM) in seawater or bacteria as suggested by several authors (Manahan 1990; Gallager 
et al. 1994; Gomme 2001). An uptake of dissolved organic materials from seawater has been documented for many species of marine invertebrates (Gomme 2001) and has been suggested to be a potentially important source of energy for larvae (Manahan 1990). Due to larval mortality in the culture tanks, populations of bacteria or heterotrophic protists may have grown in the larval cultures between water changes and might have been used as food by the surviving larvae.

Larvae fed with mono-specific diets showed a rather gradual decrease in survivorship with time. This decrease was a little bit more pronounced between days 14 and 19, when metamorphosis with major morphological and physiological changes starts and movements and feeding are reduced or inhibited.

Larval length growth rates of $R$. decussatus from hatching to metamorphosis obtained in the fed treatments (ranged between 4.93 and $5.27 \mu \mathrm{m} \mathrm{day}^{-1}$ ) were similar to those reported in previous work by our team (Matias et al. 2009) and also by Beiras and Albentosa (2004) and Ojea et al. (2008), suggesting that both mono-specific diets used in the experiment had an adequate nutritional quality. However, significant differences were observed between the two diets in terms of length, length growth rates and organic matter growth rate. The diet of $\mathrm{T}$-iso seems to be more adequate since larvae accumulated significantly more organic matter reserves in their tissues, which has allowed them to overcome more successfully the critical phase of metamorphosis (75.66\% larvae with foot). A decrease in organic matter was observed between day 19 and 23 (metamorphosis). A similar decrease in the organic content of larvae during metamorphosis had been cited by Videla et al. (1998) in Ostrea chilensis, by Rodríguez et al. (1990) and Labarta et al. (1999a, b) in O. edulis and by Moran and Manahan (2004) in C. gigas. The larvae fed with C.cal presented the highest length, suggesting that larvae fed with these microalgae seem to allocate more energy to the biosynthesis of the shell, which might have affected the success of the metamorphosis (42.81\% larvae with foot). However, the percentage of metamorphosed larvae for both diets was higher than those reported by Zine et al. (1998), Ojea et al. (2008) and Matias et al. (2009). During starvation, an increase in shell length of the clam larvae was observed. This phenomenon has also been described in other bivalves and is related to an increase in shell mass (Laing and Child 1996). It seems that the biosynthesis of the shell is a priority in the distribution of energy resources, even under extreme nutritional stress. One of the main effects of starvation in invertebrates is a decrease in metabolism down to maintenance levels (Mayzaud 1976; Albentosa et al. 1996). Under such conditions, energy is provided by body reserves and/or the catabolism of tissues. Thus, one of the first consequences of starvation is a loss of organic matter, as this was observed in the present study during the 23 days of food deprivation, especially following day 5 after fertilization. A similar decrease in organic matter has also been observed when the quantity or quality of the food provided is inadequate (Albentosa et al. 2002).

In the present study, proteins and total lipids were found to be the most important biochemical constituents of $R$. decussatus larvae, independent of the feeding regime, while carbohydrates (consisting at about $60 \%$ of free reducing sugars and at about $40 \%$ of polysaccharides) were present in lower quantities. Similar results have been reported for the early developmental stages of other bivalve species (e.g. Videla et al. 1998; Labarta et al. 1999b; Tang et al. 2005; Chaparro et al. 2006). In absolute terms, carbohydrates showed a slight increase in both mono-specific diets, while proteins and total lipids increased considerably after the early stages, reflecting an increased ingestion of particulate food. It should be noted that the increase for each biochemical component was not continuous, presenting different rates according to the stage of development. Larvae fed with $\mathrm{T}$-iso presented higher total lipids and protein contents than larvae fed with C.cal; however, no significant differences were observed between diets in terms of biochemical composition. In unfed larvae, in contrast, a decrease in proteins and total lipids was detected, while carbohydrates remained almost constant. These results suggest that total lipids and proteins are the major energy sources during larval development of $R$. decussatus, unlike the situation in adults where glycogen represents the principal energy reserves (Albentosa et al. 2006). This is also evident in the unfed larvae, in which the catabolism of proteins and total lipids contributed most to the larval metabolism, especially after day 5. Also, the high negative energy differentials observed, mainly in proteins and total lipids, in the starved larvae during the whole larval development of $R$. decussatus highlight this evidence. Neutral lipids (energetic lipids) were the most abundant lipid constituents of larvae of $R$. decussatus and the main energy source, since in the mono-specific diets, neutral lipids were accumulated in greater amounts than phospholipids after the onset of feeding, indicating that the catabolism of endogenous neutral lipids was rapidly offset by food intake during the nutritional transition. Moreover, in conditions of total starvation, energetic lipids decreased more strongly than structural lipids (phospholipids).

In the family Ostreidae, larvae undergoing metamorphosis do not feed since they have already lost the velum while gills have not yet developed. Thus, larvae in this stage use stored proteins and/or neutral lipids as shown by the decrease in the energy contribution of these components (Ferreiro et al. 1990; Rodríguez et al. 1990; Videla et al. 1998; Labarta et al. 1999a). Some authors have supported the idea that lipids, especially neutral lipids, are 
the principal energy substrate during larval development and metamorphosis (e.g. Holland and Hannant 1974; Ferreiro et al. 1990). However, Rodríguez et al. (1990) stated that proteins were more important than lipids in metamorphosis and suggested the lack of agreement being due to the differences in experimental conditions. The results of our experiment conciliate both hypotheses. While lipids (especially neutral lipids) were found to be the main source of energy during embryogenesis to the early D-veliger larvae, proteins are probably the most important substrate during metamorphosis.

Whyte et al. (1992) in their work on Crassadoma gigantea establish that the larvae best equipped to begin the process of metamorphosis present an energy content of around $6.1-6.3 \mathrm{~kJ} \mathrm{~g}^{-1}$, while the minimum premetamorphic capacity of the larvae is between 4.5 and $5.0 \mathrm{~kJ} \mathrm{~g}^{-1}$. Indeed, in our study, the larvae fed with $\mathrm{T}$-iso, with an energy content registered immediately before metamorphosis of $9.95 \mathrm{~kJ} \mathrm{~g}^{-1}$, were able to successfully begin metamorphosis $(75.66 \%)$. On the other hand, the larvae fed with C.cal which presented a value of $3.98 \mathrm{~kJ} \mathrm{~g}^{-1}$, slightly inferior to the minimum premetamorphic suggested by Whyte et al. (1992), presented considerable lower levels of metamorphosis success (42.81\%). Moreover, these results support the fact that the T-iso diet is more adequate for $R$. decussatus larval rearing than the C.cal one.

Our results indicate that egg reserves could energetically contribute to the maintenance of larvae beyond the embryonic phase. Obviously, the transition from the endotrophic to the exotrophic phase in the early development of $R$. decussatus larvae is a gradual process, with the existence of an intermediate, mixotrophic phase, in which yolk reserves and planktonic particles are used simultaneously by young larvae. The endotrophic phase largely corresponds to the first 2 days after fertilization. It is followed by a mixotrophic phase from day 2 to approximately days $5-8$, after which the larvae are exclusively exotrophic. The mixo- and exotrophic phases involve a period of growth with deposition of the prodissoconch II shell as well as increase in the visceral mass and in velum size. Thereafter, around day 20, metamorphosis occurs, starting with the development of the foot and the primary gill filaments and culminating in larval settlement. This intense morphogenetic activity is supported by energy originating from proteins that are accumulated during the planktonic larval phase.

Beyond its contribution to our general knowledge of the biochemical dynamics in the early developmental phases of $R$. decussatus, the present study provides some useful information for hatchery production programs of this clam: 1. Among mono-specific algal diets, T-iso seems to be more adequate than C.cal. 2. Food should not be administered until after day 2 following fertilization (endotrophic phase), and thereafter, food supply should be rather moderate until day 8 (mixotrophic phase).

Acknowledgments The authors are grateful to J. White for revising the English. Thanks are also due to António Machado for maintaining the larvae. The study was funded by the project 0251_ECOAQUA_5_E-Programa POCTEP.

\section{References}

Albentosa M, Pérez-Camacho A, Labarta U, Fernández-Reiriz MJ (1996) Evaluation of live microalgal diets for the seed culture of Ruditapes decussatus using physiological and biochemical parameters. Aquaculture 148:11-23

Albentosa M, Pérez-Camacho A, Fernández-Reiriz MJ, Labarta U (2002) Wheatgerm flour in diets for Manila clam, Ruditapes philippinarum, spat. Aquaculture 212:335-345

Albentosa M, Fernández-Reiriz MJ, Labarta U, Pérez-Camacho A (2006) Response of two species of clams, Ruditapes decussatus and Venerupis pullastra, to starvation: physiological and biochemical parameters. Comp Biochem Phys B 146:241-249

Bartlett BR (1979) Biochemical changes in the Pacific oyster, Crassostrea gigas (Thunberg 1795) during larval development and metamorphosis. Proc Natl Shellfish Ass 6:202 (Abstract)

Bayne BL (1973) Aspects of the metabolism of Mytilus edulis during starvation. Neth J Sea Res 7:399-441

Bayne BL, Gabbott PA, Widdows J (1975) Some effects of stress in the adult on the eggs and larvae of Mytilus edulis L. J Mar Biol Ass UK 55:675-689

Beiras R, Albentosa M (2004) Inhibition of embryo development of the commercial bivalves Ruditapes decussatus and Mytilus galloprovincialis by trace metals; implications for the implementation of seawater quality criteria. Aquaculture 230:205-213

Bensadoun A, Weinstein D (1976) Assay of proteins in the presence of interfering materials. Analyt Biochem 70:241-450

Beukema JJ, De Bruin W (1979) Calorific values of the soft parts of the tellinid bivalve Macoma balthica (L.) as determined by two methods. J Exp Mar Biol Ecol 37:19-30

Bligh EG, Dyer WJ (1959) A rapid method for total lipid extraction and purification. Can J Biochem Physiol 37:911-917

Chaparro OR, Navarrete LR, Thompson RJ (2006) The physiology of the larva of the Chilean oyster Ostrea chilensis and the utilisation of biochemical energy reserves during development: an extreme case of the brooding habit. J Sea Res 55:292-300

Chícharo L, Chícharo MA (2001) Effects of environmental conditions on planktonic abundances, benthic recruitment and growth rates of the bivalve mollusc Ruditapes decussatus in a Portuguese coastal lagoon. Fish Res 53:235-250

Collyer DM (1957) Viability and glycogen reserves in the newly liberated larvae of Ostrea edulis. J Mar Biol Ass UK 36:335-337

Delaunay F (1992) Nutrition lipidique de la coquille Saint-Jacques Pecten maximus (L.) au cours du developpement larvaire. Dissertation, University of Brest

Ferreiro MJ, Pérez-Camacho A, Labarta U, Beiras R, Planas M, Fernández-Reiriz MJ (1990) Changes in the biochemical composition of Ostrea edulis larvae fed on different food regimes. Mar Biol 106:395-401

Folin O, Malmros H (1929) Micro-method for glucose determination in $0.1 \mathrm{ml}$ of blood. J Biol Chem 83:115

Gabbott PA (1976) Energy metabolism. In: Bayne BL (ed) Marine mussels: their ecology and physiology. International biological programme, vol 10. Cambridge University Press, London, pp 293-355 
Gallager SM, Mann R (1986) Individual variability in lipid content of bivalve larvae quantified histochemically by absorption photometry. J Plankton Res 8:927-937

Gallager SM, Mann R, Sasaki GC (1986) Lipid as an index of growth and viability in three species of bivalve larvae. Aquaculture $56: 81-103$

Gallager SM, Waterbury JB, Stoecker DK (1994) Utilization of the marine cyanobacterium Synechococcus sp. by larvae of the bivalve Mercenaria mercenaria. Mar Biol 119:251-259

Gomme J (2001) Transport of exogenous organic substances by invertebrate integuments: the field revisited. J Exp Zool 289:254265

Guillard RRL (1975) Culture of phytoplankton for feeding marine invertebrates. In: Smith WL, Chanley MH (eds) Culture of marine invertebrate animals. Plenum Press, New York, pp 26-60

Haws MC, DiMichele L, Hand SC (1993) Biochemical changes and mortality during metamorphosis of the Eastern oyster, Crassostrea virginica, and the Pacific oyster, Crassostrea gigas. Mol Mar Biol Biotech 2:207-217

Helm MM, Holland DL, Stephenson RR (1973) The effect of supplementary algal feeding of a hatchery breeding stock of Ostrea edulis L. on larval vigour. J Mar Biol Ass UK 53:673684

Hess HH, Lees JE, Derr JE (1978) A linear Lowry-Folin assay for both water soluble and sodium dodecyl sulfate solubilized proteins. Anal Biochem 85:259-300

Holland DL (1978) Lipid reserves and energy metabolism in the larvae of benthic marine invertebrates. In: Malins PL, Sargent JR (eds) Biochemical and biophysical perspectives in marine biology. Academic Press, London, pp 85-123

Holland DL, Gabbott PA (1971) Micro-analytical scheme for determination of protein, carbohydrate, lipid and RNA levels in marine invertebrate larvae. Mar Freshw Biol 51:659-668

Holland DL, Hannant PJ (1973) Addendum to a microanalytical scheme for the biochemical analysis of marine invertebrate larvae. J Mar Biol Ass UK 53:833-838

Holland DL, Hannant PJ (1974) Biochemical changes during growth of the spat of the oyster, Ostrea edulis L. J Mar Biol Ass UK 54:1007-1016

Holland DL, Spencer BE (1973) Biochemical changes in fed and starved oysters, Ostrea edulis L. during larval development, metamorphosis and early spat growth. J Mar Biol Ass UK 53:287-298

Labarta U, Fernandez-Reiriz MJ, Pérez-Camacho A (1999a) Energy, biochemical substrates and growth in the larval development, metamorphosis and postlarvae of Ostrea edulis (L.). J Exp Mar Biol Ecol 238:225-242

Labarta U, Fernandez-Reiriz MJ, Pérez-Camacho A (1999b) Larvae of Ostrea edulis (L.) during starvation: growth, energy and biochemical substrates. Hydrobiologia 405:125-131

Laing I, Child AR (1996) Comparative tolerance of small juvenile palourdes (Tapes decussatus L.) and Manila clams (Tapes philippinarum Adams \& Reeve) to low temperature. J Exp Mar Biol Ecol 195:267-285

Lowry O, Rosenbrough NM, Farr A, Randall J (1951) Protein measurement with the Folin phenol reagent. J Biol Chem 193:265-275
Lucas A, Chebab-Chalabi L, Aranda D (1986) Passage de l'endotrophie à l'ecotrophie chez les larves de Mytilus edulis. Oceanol Acta 9:97-103

Manahan DT (1990) Adaptations by invertebrate larvae for nutrient acquisition from seawater. Am Zool 30:147-160

Marsh JB, Weinstein DB (1966) Simple charring method for determination of lipids. J Lipid Res 7:574-576

Matias D, Joaquim S, Leitão A, Massapina C (2009) Effect of geographic origin, temperature and timing of broodstock collection on conditioning, spawning success and larval viability of Ruditapes decussatus (Linné, 1758). Aquacult Int 17:257-271

Mayzaud P (1976) Respiration and nitrogen excretion of zooplankton. IV. The influence of starvation on the metabolism and the biochemical composition of some species. Mar Biol 37:47-58

Millar RH, Scott JM (1967) The larva of the oyster Ostrea edulis during starvation. J Mar Biol Ass UK 47:475-484

Moran AL, Manahan DT (2004) Physiological recovery from prolonged starvation in larvae of the Pacific oyster Crassostrea gigas. J Exp Mar Biol Ecol 306:17-36

Ojea J, Pazos AJ, Martínez D, Novoa S, García-Martínez P, Sánchez JL, Abad M (2008) Effects of temperature regime on broodstock conditioning of Ruditapes decussatus. J Shellfish Res 27:10931100

Pernet F, Bricelj VM, Cartier S (2004) Lipids class dynamics during larval ontogeny of sea scallops, Placopecten magellanicus, in relation to metamorphic success and response to antibiotics. J Exp Mar Biol Ecol 329:265-280

Rico-Villa B, Pouvreau S, Robert R (2009) Influence of food density and temperature on ingestion, growth and settlement of Pacific oyter larvae, Crassostrea gigas. Aquaculture 207:395-401

Rodríguez JL, Sedano FJ, García-Martín LO, Peréz-Camacho A, Sánchez JL (1990) Energy metabolism of newly settled Ostrea edulis spat during metamorphosis. Mar Biol 106:109-111

Sokal RR, Rohlf FJ (1981) Biometry: the principles and practice of statistics, 2nd edn. Freeman, San Francisco

Tang B, Liu B, Wang G, Zhang T, Xianga J (2005) Effects of various algal diets and starvation on larval growth and survival of Meretrix meretrix. Aquculture 254:523-533

Utting SD, Millican PF (1997) Techniques for the hatchery conditioning of bivalve broodstocks and the subsequent effect on egg quality and larval viability. Aquaculture 155:45-54

Videla JA, Chaparro OR, Thompson RJ, Concha II (1998) Role of biochemical energy reserves in the metamorphosis and early juvenile development of the oyster Ostrea chilensis. Mar Biol 132:635-640

Whyte JNC, Bourne N, Hodgson CA (1990) Nutritional condition of rock scallop, Crassadoma gigantea (Gray), larvae fed mixed algal diets. Aquaculture 86:25-40

Whyte JNC, Bourne N, Ginther NG, Hodgson CA (1992) Compositional changes in larva to juvenile development of the scallop Crassadoma gigantean (Gray). J Exp Mar Biol Ecol 163:13-29

Zine NE, Menioui M, Zaouali J (1998) Preliminary study of the embryology, larval and juvenile life of the clam Ruditapes decussatus (L.) in controlled environment. Mar Life 8:19-24 